Egyptian Journal of Rabbit Science, 31(1): 73-90 (2021)

\title{
EFFECT OF USING VARYING LEVELS OF QUINOA HAY IN GROWING RABBIT RATIONS
}

\author{
H. A. Abo-Eid' ; S. S. Eisa ${ }^{2}$; F. Abdel-Azeem ${ }^{3}$ and N. E. El-Bordeny ${ }^{4}$ \\ ${ }^{I}$ Sustainable Development of Environment and its Project Management Department, \\ Environmental Studies and Research Institute, University of Sadat City, Menofiya, Egypt. \\ ${ }^{2}$ Agriculture Botany Department, Faculty of Agriculture, Ain Shams University, Cairo, Egypt. \\ ${ }^{3}$ Poultry Production Department, Faculty of Agriculture, Ain Shams University, Cairo, Egypt . \\ ${ }^{4}$ Animal Production Department, Faculty of Agriculture, Ain Shams University, Cairo, Egypt. \\ Corresponding author: H. A. Abo-Eid; Email: hosni.aboeid@esri.usc.edu.eg \\ hosny_abo_eid@yahoo.com;
}

\begin{abstract}
The present study was carried out to investigate the effect of using varying levels of quinoa hay as a replacer of 25,50 and $75 \%$ of dietary alfalfa hay as a source of fiber in growing New Zealand White rabbits (NZW) rations on their productive performance. Sixty-four growing NZW rabbits of 5 weeks' age with average initial live body weight of $623.69 \pm 7.73 \mathrm{~g}$ were randomly divided into four similar groups, sixteen growing rabbits in each group.

Insignificant $(P>0.05)$ differences in feed consumption between different experimental groups were observed during all experimental periods (5-9 weeks of age, 9-15 weeks of age and the entire of the experimental period 5-15 weeks of age). Replacement of alfalfa hay with 25\%, 50\% and $75 \%$ quinoa hay reduced the values of all nutrient digestibility coefficients. The group of rabbits that received $25 \%$, $50 \%$ and $75 \%$ quinoa hay showed significantly lower values of TDN and DCP compared to control group

(0\%). The group fed diet contain $25 \%$ quinoa hay gave insignificant improvement $(P>0.05)$ of feed conversion ratio compared with those fed control group, $50 \%$ and $75 \%$ quinoa hay at 9-15 weeks and entire experimental period (5-15 weeks). An insignificant increase $(P>0.05)$ was observed in the values of total protein, albumin and globulin in rabbits group received $25 \%$ quinoa hay compared to the control group. Insignificantly $(P>0.05) \quad$ higher values of blood urea were observed for the groups received quinoa hay compared to control group. Also, there was no significant difference between control group and groups that received quinoa hay for GOT and GPT values. The level of triglycerides insignificantly decreased ( $P>0.05)$ after adding quinoa hay to the ration. Insignificantly $(P>0.05)$ decrease in plasma cholesterol concentration was observed by consuming quinoa hay compared to control group. Using the level of $25 \%$ from quinoa hay did not
\end{abstract}


affect creatinine level compared to successfully used quinoa hay with control group. While, a significant $25 \%$ as a source of fiber to replace increase $(P<0.05)$ was observed in alfalfa hay in the rabbit ration the values of creatinine in the rabbit's without any negative effect on rabbit groups received $50 \%$ and $75 \%$ performance.

compared to that received 25\% Keywords: Quinoa hay, Rabbits, quinoa hay and control group. nutritive value, performance, Conclusively, based on the results digestibility, blood parameters. obtained in this study, it can be

\section{INTRODUCTION}

In Egypt, affected regions with dry and salt suffer from a shortage of fodder crops production because of many environmental factors, such as soils salinity, groundwater and water scarcity. The quinoa is tolerant of cold, salinity and drought and can be cultivated in highlands in the mountain areas (Jacobsen et al., 2003; Bhargava et al., 2007). There is great technological and commercial interest in this crop, not only for purpose of human nutrition but also because of the release of by-products which are of great importance to the pharmaceutical industry and also considered good nutritional alternatives to animal nutrition (Blanco Callisaya, 2015; Efe, 2017 and Peiretti, 2019). Quinoa is used as fodder for ruminants, in regions where other species cannot grow because of the prevalent soil and climate conditions (e.g. in the nearness of the salt swamp regions (Capelo Baez, 1979).

Quinoa can grow in a wide range of soil $\mathrm{pH}$, including acidic soil, and can withstand poor and coarse environments. This crop is ideally grown at high altitudes, where maize cannot be grown, and ripens within 4 to 7 months, depending on diversity or ecology (Carmen, 1984). Rosero et al. (2010) indicated that a low percentage of Colombian farmers $(20 \%)$ use quinoa in animal feed. Researchers in Denmark demonstrated that when using quinoa as silage this could be a good forage crop for dairy farms with yields that have high protein content (Darwinkel and Stolen, 1998 and Peiretti et al., 2013). Marino et al. (2018) investigate the effect of diet supplementation with quinoa seed and/or linseed. They found that there were no significant differences in the average daily gain, slaughter weight, carcass weight and dressing percentage among all experimental groups. Mosquera et al. (2009) stated that the control group provided the best yield and the quinoa diets gave the lowest yields (gain of broiler), but the mortality rate was higher in the control group (10.94\%) and lowest in the quinoa group $(1.56 \%)$. In the study of quinoa at six morphological stages, Peiretti et al. (2013) reported that the in vivo dry matter digestibility was 
$0.92 \mathrm{~g} / \mathrm{g}$ dry matter in early vegetative and $0.85 \mathrm{~g} / \mathrm{g}$ dry matter in late vegetative. Bhargava et al. (2006), Vilcacundo and Hernandez (2017) and Peiretti (2019) stated that the quinoa whole plant has been also used as a rich nutritional source to feed livestock, including cattle, pigs, and poultry. Also, residues of harvest are used to feed cattle, sheep, horses, pigs, and poultry (FAO, 1994). BarrosRodríguez et al. (2018) reported that the whole quinoa plant can be integrated into the rations of ruminants due to its good chemical composition, high rumen digestion and reduced protozoa as well as, the saponins of quinoa in the ration of ruminants may be reduce greenhouse gases, without any effect on the digestion of nutrients. There are a few numbers of studies on the using quinoa in animal rations.

So, the objective of the current study is to evaluate the effect of using varying levels of quinoa hay in growing rabbits ration on their productive performance.

\section{MATERIALS AND METHODS}

The present study was carried out in the Center of Agriculture Studies and Consultations (CASC), Rabbits Production Unit (RPU), labs of Animal Nutrition, Animal Production Department, Faculty of Agriculture, Ain Shams University, Cairo, Egypt.

\section{Quinoa hay processing}

The quinoa plants were harvested at 90 days after sowing date and collected at plastic sheet at sunny place for 3 weeks until air dried. The plants were turned over every 2 days to get good aeration.

\section{Experimental rabbits}

Sixty-four growing New Zealand White (NZW) rabbits with average initial live body weight of $623.69 \pm 7.73 \mathrm{~kg}$ were randomly divided into four similar groups, sixteen growing rabbits in each group. Each group was divided into four replicates. Each replicate consists of 4 rabbits and the initial live body weight of all experimental groups was almost equal. The rabbits were weighed biweekly to calculate total gain, daily gain and feed conversion.

\section{Experimental diet}

Four pelleted experimental diets were formulated to be approximately isocaloric, isonitrogenous and isofiberous. All experimental diets were formulated at Atmida Company to meet the recommended nutrient requirements of rabbits according to NRC (1977) 
and Cheeke (1987), but with replacement alfalfa hay by quinoa hay levels $0,25,50$ and $75 \%$. Chemical composition of alfalfa hay and quinoa hay, as well as, ingredient and experimental diets are shown in Tables (1 and 2).

\section{Management}

The experimental rabbits were housed in galvanized metal cages. Each cage was $60 \times 50 \times 40 \mathrm{~cm}$ for length, width and height respectively, and provided with feeders and automatic watering system, with four rabbits per each cage. The cages were located in a naturally ventilated and lighting building. The experimental diets were offered to the rabbits ad libitum and fresh water available all the time during the experimental period. Rabbits were individually weighed at the beginning of the experiment, then at weekly intervals until the end of experiment. Daily weight gain, daily feed conversion, feed conversion ration and mortality rate were calculated. The feeding trail was conducted for 10 weeks.

\section{Carcass characteristics and blood samples}

At the end of the trails, five randomly chosen rabbits representing each group were slaughtered according to the standard technique of Cheeke (1987). Dressing percentage included relative weights of carcass, giblets and head. Blood samples were collected at slaughtering in unheparinize glasses tube (5 samples/treatment).

Blood serum was separated by centrifugation at $3000 \mathrm{rpm}$ for 15 minutes. The collected serum was stored at $-20 \mathrm{C}^{0}$ until assay. Values of total protein, albumin, total lipids, total cholesterol and urea-N, Alkaline phosphatase $(\mathrm{u} / \mathrm{L})$, Triglyceride, Creatinine and transaminase enzymes activities (GOT and GPT) were determined by using kits purchased from Diamond Diagnostics Company, Egypt. The globulin values were obtained by subtracting the values of albumin from the corresponding values of total protein.

\section{Chemical analysis}

The chemical composition of the quinoa hay, alfalfa, experimental diet and feces were analyzed according to AOAC (2016). The total digestible nutrients (TDN) were calculated according to the classic formula (Cheeke et al., 1982).

Neutral detergent fiber (NDF), assayed without using sodium sulfite and expressed inclusive of residual ash and acid detergent fiber (ADF), expressed inclusive of residual ash were determined according to Van Soest et al. (1991). 
Table 1. Chemical composition of Alfalfa hay and Quinoa hay.

\begin{tabular}{lcc}
\hline Chemical contents, $\boldsymbol{g} / \mathbf{k g}$ DM & & \\
\hline Items & Alfalfa hay & Quinoa hay \\
\hline Dry matter & 889.50 & 963.40 \\
Organic matter & 878.70 & 755.50 \\
Ash & 121.30 & 244.50 \\
Silica & 13.80 & 20.50 \\
Crude protein & 208.50 & 139.00 \\
Crude fiber & 308.80 & 227.40 \\
Ether extract & 28.40 & 26.10 \\
Natural detergent fiber & 460.60 & 476.10 \\
Acid detergent fiber & 359.70 & 348.90 \\
Acid detergent lignin & 41.60 & 102.10 \\
Cellulose & 318.10 & 246.80 \\
Hemicelluloses & 101.00 & 127.30 \\
Non fiber carbohydrate & 181.20 & 114.30 \\
\hline Mineral contents & & 39.00 \\
\hline Sodium $(\mathrm{Na}) \mathrm{mg} / \mathrm{kg}$ & 6.40 & 72.00 \\
Potassium $(\mathrm{K}) \mathrm{mg} / \mathrm{kg}$ & 36.70 & 22.00 \\
Calcium $(\mathrm{Ca}) \mathrm{mg} / \mathrm{kg}$ & 30.70 & 12.00 \\
Magnesium $(\mathrm{Mg}) \mathrm{mg} / \mathrm{kg}$ & 4.60 & 57.50 \\
Manganese $(\mathrm{Mn}), \mathrm{mg} / \mathrm{kg}$ & 48.75 & 0.40 \\
Phosphorus $(\mathrm{P}), \mathrm{mg} / \mathrm{kg}$ & 0.33 & 1375.0 \\
Iron (Fe), mg/kg & 2049.0 & 7.50 \\
Zinc $(\mathrm{Zn}), \mathrm{mg} / \mathrm{kg}$ & 12.00 & 8.00 \\
Copper $(\mathrm{Cu}), \mathrm{mg} / \mathrm{kg}$ & 4.50 & 3.88 \\
\hline Phytochemical contents & & 104.91 \\
\hline Total phenols mg/g & 3.55 & \\
Oxalate mg/100g & 38.54 & \\
\hline
\end{tabular}

\section{Phytochemical component}

The total soluble oxalic acid (OA) concentration of quinoa hay and alfalfa hay was determined according to $\mathrm{Xu}$ and Zhang (2000). Determination of total soluble phenols was performed as described by Shahidi and Naczk (1995).

\section{Digestibility trials}

Digestion trials were conducted at the end of growth trial to determine the digestibility values and nutritive value of the experimental diets expressed as total digestible nutrients (TDN, \%), digestible energy (DE, Kcal/Kg feed) 
ABO-EID et al.

Table 2. Formulation and chemical composition of the experimental diets.

\begin{tabular}{|c|c|c|c|c|}
\hline Ingredients & $\begin{array}{c}\mathbf{0 \%} \\
\text { quinoa }\end{array}$ & $\begin{array}{c}25 \% \\
\text { quinoa }\end{array}$ & $\begin{array}{c}\mathbf{5 0 \%} \\
\text { quinoa }\end{array}$ & $\begin{array}{c}75 \% \\
\text { quinoa }\end{array}$ \\
\hline Barley & 20 & 20 & 20 & 20 \\
\hline Corn & 10 & 10 & 10 & 10 \\
\hline Soybeen & 17.25 & 17.95 & 18.55 & 20.38 \\
\hline W.BRAN & 20 & 19.5 & 19 & 17.6 \\
\hline Quinea & 0 & 7.5 & 15 & 22.5 \\
\hline Alfa alfa hay & 30 & 22.5 & 15 & 7.5 \\
\hline Oil & 0.3 & 0.3 & 0.3 & 0.2 \\
\hline Limst & 0.7 & 0.6 & 0.5 & 0.3 \\
\hline Salt & 0.5 & 0.4 & 0.4 & 0.2 \\
\hline Meth & 0.1 & 0.1 & 0.1 & 0.17 \\
\hline Premix Mixture ${ }^{*}$ & 0.3 & 0.3 & 0.3 & 0.3 \\
\hline Dical & 0.85 & 0.85 & 0.85 & 0.85 \\
\hline Total & 100 & 100 & 100 & 100 \\
\hline \multicolumn{5}{|c|}{ Chemical composition (as feed basis) } \\
\hline Dry Matter(DM\%) & 91.32 & 90.93 & 91.80 & 91.39 \\
\hline Organic matter (OM\%) & 89.51 & 90.08 & 89.21 & 89.50 \\
\hline Crude protein $(\mathrm{CP} \%)$ & 21.11 & 21.47 & 22.07 & 23.37 \\
\hline Crude fiber (CF\%) & 11.81 & 11.70 & 11.27 & 11.97 \\
\hline Ether extract (EE\%) & 2.95 & 4.30 & 2.49 & 3.68 \\
\hline Nitrogen free extract (NFE\%) & 53.64 & 51.97 & 50.19 & 50.17 \\
\hline Crude ash $(\%)$ & 10.49 & 9.92 & 10.79 & 10.50 \\
\hline $\operatorname{NDF}(\%)$ & 40.11 & 36.00 & 39.14 & 37.80 \\
\hline $\operatorname{ADF}(\%)$ & 16.11 & 14.76 & 15.27 & 15.01 \\
\hline $\operatorname{ADL}(\%)$ & 4.69 & 4.63 & 4.14 & 4.82 \\
\hline $\operatorname{Lignin}(\%)$ & 3.52 & 4.21 & 2.02 & 3.46 \\
\hline
\end{tabular}

"Each one kg of vitamin \& mineral mixture contains: Vit.A 4000000 IU; Vit D3 50000IU; Vit E 16.7g.; Vit K3, 0.67g.; Vit.B1 67g; VitB2 2.00g; Vit. B6 $0.67 \mathrm{~g}$; Vit B12 $3.33 \mathrm{mg}$; Cholin chloride 400g.; Biotin 0.07g ;Niacin 16.7g.; pantothenic acid 6.7g; Folic acid 1.7g;; Copper 1.7g; Iron 25.00g; Manganese 10.00g; Iodine $0.25 \mathrm{~g}$; Selenium $33.3 \mathrm{~g}$; Zinc 23.3g and Magnesium 133.3g.

and digestible crude protein (DCP, \%). Four animals representing each group were individually housed in metabolic cages equipped with a stainless- steel screen and $4 \mathrm{~mm}$ mesh to retain feces but allow free passage of urine. Feed and water intake were offered to rabbits adlibitum, during the digestion trial. The digestion trial lasted for 10 days as preliminary period while the collection period lasted for 5 days in which feces was collected daily before the morning meal, weighed fresh and sprayed with $2 \%$ boric acid for trapping any ammonia released from 
feces and dried at $60{ }^{\circ} \mathrm{C}$ for $24 \mathrm{hrs}$ in an air drying oven. The feces were then ground and mixed, stored for subsequent chemical analysis. Samples of diets and feces were chemically analyzed to determine the digestibility coefficients and nutritive values of the experimental diets.

\section{Statistical analysis:}

The data were analyzed according to statistical analysis system (SAS) User's Guide (2003). Nutrient digestibility, feeding values, and blood parameters were analyzed by the following model to describe the data:

$$
Y_{i j}=\mu+T_{i}+e_{i j}
$$

Where, $Y_{i}=$ The observation of the $i^{\text {th }}$ treatment, $\mu=$ Overall mean, $T_{i}=$ Effect of the $i^{\text {th }}$ treatments and $\mathrm{e}_{\mathrm{i}}=$ Experimental error.

Separation among means was carried out by using Duncan multiple tests (Duncan, 1955).

\section{RESULTS AND DISCUSSION}

\section{Chemical composition}

The data of chemical composition and minerals contents of quinoa hay compared to alfalfa hay are presented in Table 1 . The data showed that quinoa hay recorded lower OM content compared to alfalfa hay (755.50 vs. 878.70 $\mathrm{g} / \mathrm{kg}$ ) and vise versa quinoa hay recorded higher ash content compared to alfalfa hay ( 244.50 vs. $121.30 \mathrm{~g} / \mathrm{kg}$ ). The CF and EE content in quinoa hay were lower than alfalfa hay (227.40 vs. 308.80 and 26.10 vs. $28.40 \mathrm{~g} / \mathrm{kg}$, respectively).

The cell wall contents of quinoa hay as NDF, ADF and ADL were close to those recorded for alfalfa hay (Table 1). Values of NDF and ADF were close to those recorded by Peiretti et al. (2013) who found that NDF and ADF content in quinoa plants were 493.7 and 331.3, respectively.

The minerals contents in quinoa hay as $\mathrm{Na}, \mathrm{K}, \mathrm{Mg}, \mathrm{P}, \mathrm{Mn}$ and $\mathrm{Cu}$ were higher than those in alfalfa hay, which support the higher Ash content of quinoa hay compared to alfalfa hay, while $\mathrm{Ca}, \mathrm{Zn}$ and $\mathrm{Fe}$ were lower in quinoa hay than alfalfa hay (Table 1).

Quinoa hay had higher oxalate content than those of alfalfa hay, while total phenols content was similar for both plants hay (Table 1).

The different formulations of experimental diets are presented in Table 2. The different ingredients were used by different ratios to formulate the diets to be approximately isocaloric, isonitrogenous and isofibrous. 


\section{Feed consumption}

Feed consumption, nutrients digestibility coefficients and nutritive values of the experimental diets are presented in Table 3. The results showed insignificant $(\mathrm{P}>0.05)$ differences in feed consumption between different experimental groups during all experimental periods (5-9 weeks of age, 9-15 weeks of age and 5-15 weeks of age). The average feed intake was low during the first period and then increased during the second period. These results are in agreement with NRC (1977) who reported that rabbits, like most animals, are adjusting their feed intake to meet their needs.

The results of feed intake in Table 3 may indicate that the palatability of quinoa hay is similar to that in alfalfa hay which not affect feed intake. Also, sodium content in quinoa hay had no negative effect on feed intake. Wang et al. (2011) replaced 33.3, 66.7, and 100 corn stover with salinity tolerant plants and found no significant effect on feed intake.

\section{Nutrient digestibility coefficient}

Replacement of alfalfa hay by $25 \%, 50 \%$ and $75 \%$ quinoa hay reduced the values of all nutrient digestibility coefficients (Table 3). The group of rabbits that received $25 \%, 50 \%$ and $75 \%$ quinoa hay showed significantly $(\mathrm{P}<0.05)$ lower values of TDN and DCP compared to control group.

\section{Growth performance}

\section{Live body weight}

Rabbits performance of the experimental diets are presented in Table 4. The results showed that insignificant differences in the initial body weight were observed at 5 weeks of age. During the first period (4 weeks after weaning), it may be noted that rabbit feeding on diets containing quinoa hay as a substitute for alfalfa hay as a major source of fiber, grew slower $(\mathrm{P}>0.05)$ than the control group. Also, insignificant differences were observed in average daily gain during the period 9-15 weeks of age. The same trend was obtained during the whole trial period (5-15 weeks of age). This may be due to the similar crude protein and metabolizable energy level of diets. These results are in agreement with Marino et al. (2018).

\section{Feed conversion}

During the first trial period (5-9 weeks), the values of feed conversion ratio were not significantly affected $(\mathrm{P}>0.05)$ by using quinoa hay as a substitute for alfalfa hay (Table 4). These results are in agreement with El 


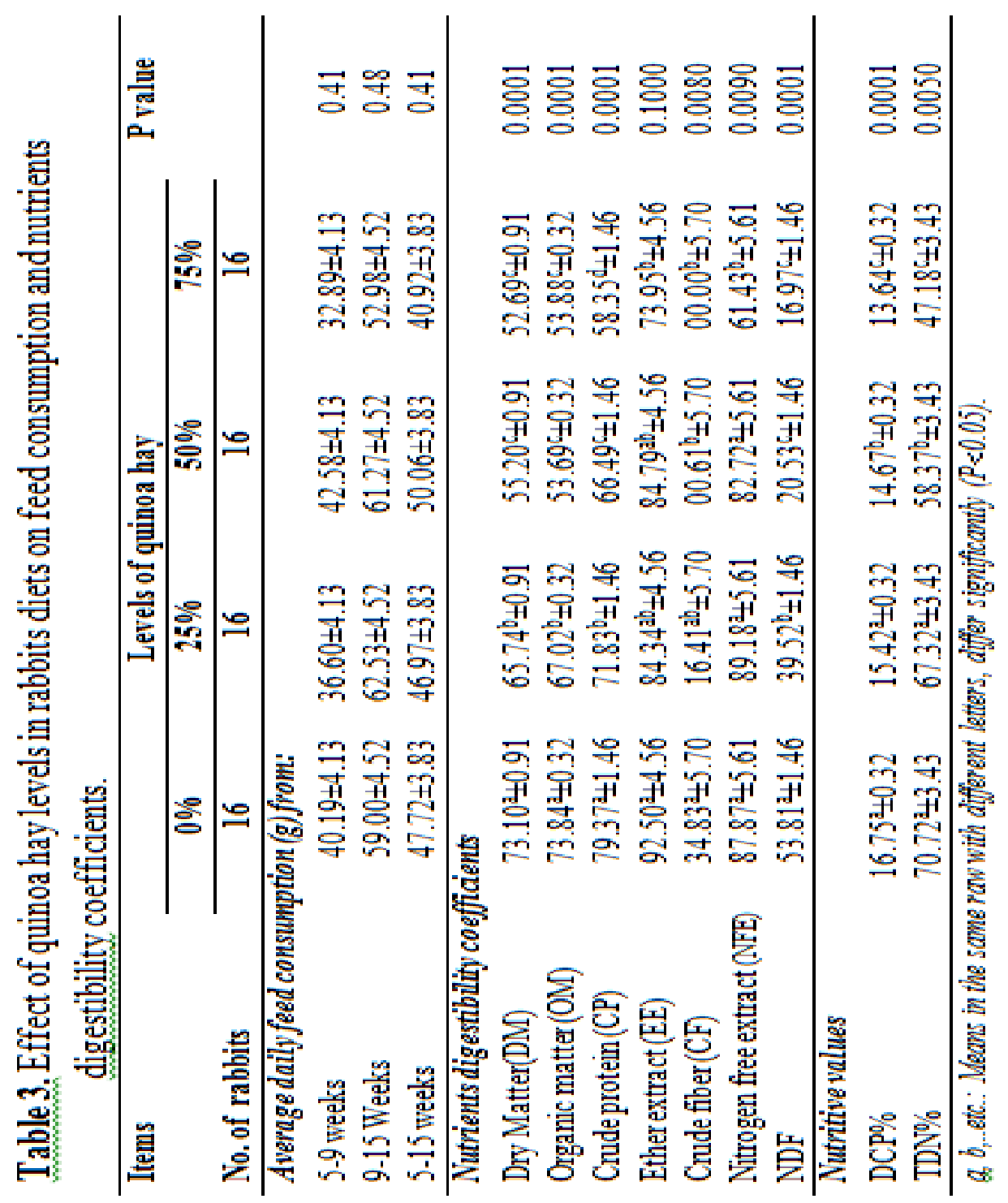


ABO-EID et al.

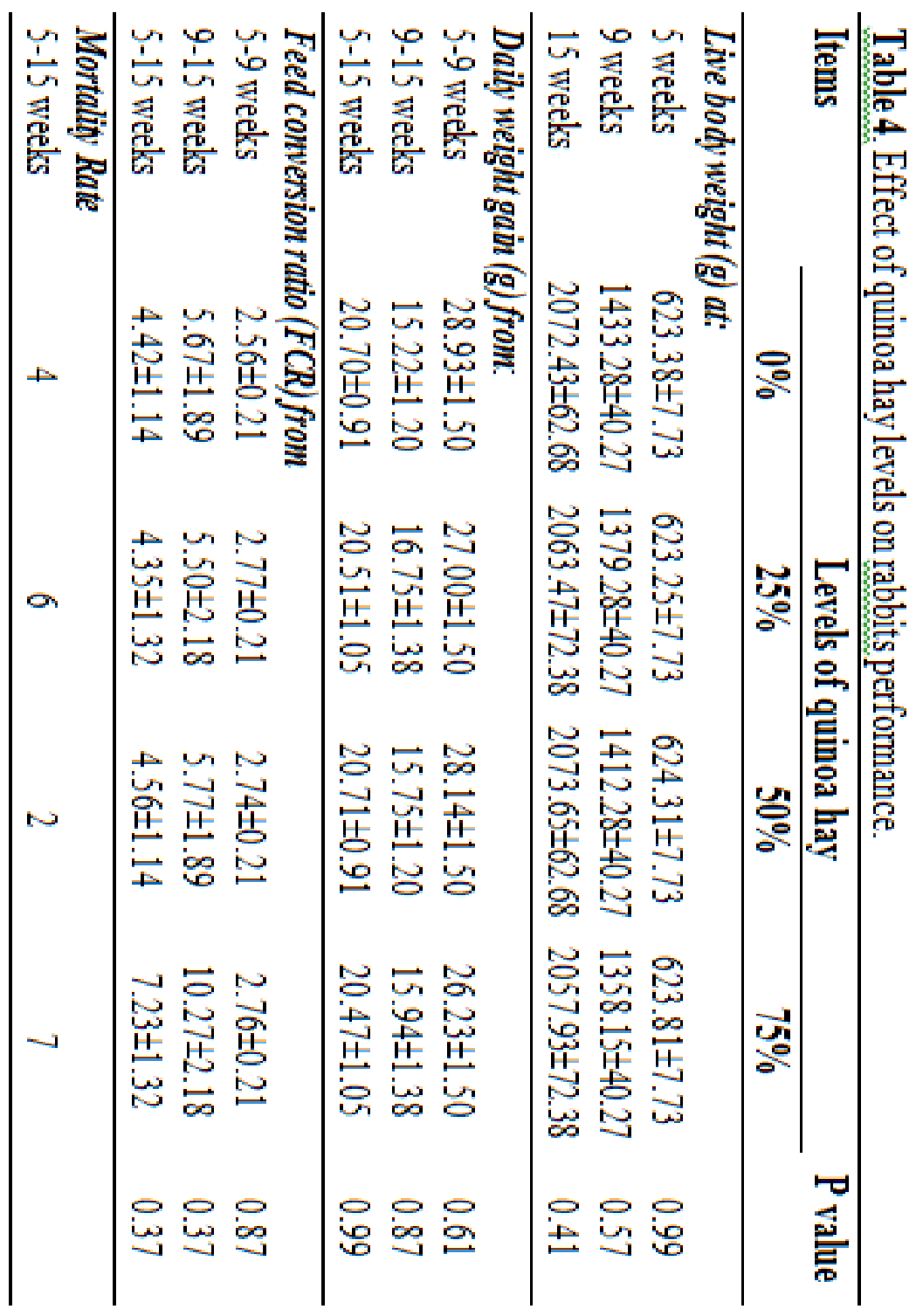


Sayed (2016) who reported that insignificant differences in the feed conversion may be due to the close values of feed intake parallel to the average daily gain values. While the group fed on $25 \%$ of quinoa hay (Table 4) gave insignificant improvement $(\mathrm{P}>0.05)$ of feed conversion ratio compared with those fed control group, 50\% and 75\% quinoa hay at 9-15 weeks and entire experimental period (5-15 weeks). These results may be due to the improvement of daily weight gain.

\section{Mortality rate}

Table 4 showed death losses during entire experimental period either for group fed on alfalfa hay or the groups fed quinoa hay as a substitute of alfalfa hay. This may be due to management conditions.

\section{Blood parameters}

The effect of quinoa hay levels on blood parameters is shown in Table 5. An insignificant increase $(\mathrm{P}>0.05)$ was observed in the values of total protein, albumin and globulin in rabbit group received $25 \%$ quinoa hay compared to the control group. These results can be attributed to the fact that the different rations are approximately isocaloric, isonitrogenous and isofibrous. AbdelAzeem and El-Bordeny (2007) reported a positive correlation between the concentration of dietary protein and plasma protein. Also, the same author mentioned that the low level of plasma proteins may be due to a decrease in the protein that is absorbed and synthesized and an increase in protein loss. Ashour et al. (2004) reported that albumin concentration was considered a reflection of the animal ability to synthesize and store protein. Jones and Bark (1979) stated that the site of synthesis albumin is the liver, while lymphoid tissue is the one that forms globulin.

The values of total plasma protein and its fractions in this study were within the normal range and near to the values of Abdel-Azeem and ElBordeny (2007) and higher than the levels in study of Wang et al. (2017). The different values might be due to the differences in age and growth period of the animals.

Insignificantly $(\mathrm{P}>0.05)$ higher values of urea-N were observed for the groups received quinoa hay compared to control group (Table 5). Also, there was no significant difference between control group and groups that received quinoa hay for GOT and GPT values. These results are consistent with Gugołek et al. (2018) who reported that quinoa (Chenopodium quinoa) seeds as a protein supplement with less than $100 \mathrm{~g} / \mathrm{kg}$ are useful and safe in use for feeding broiler without any adverse effects on liver functions GOT and GPT. 
ABO-EID et al.

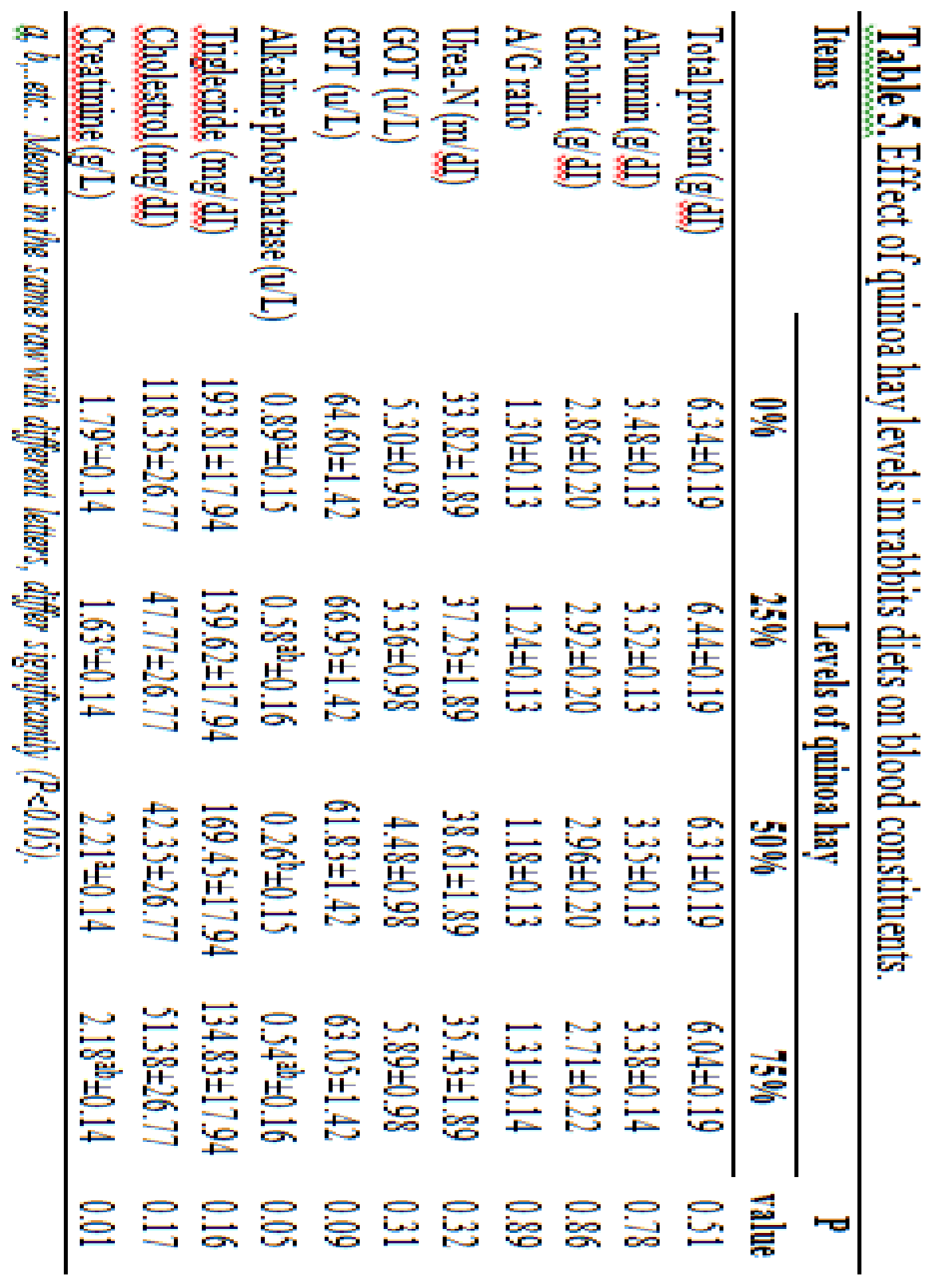


The level of triglycerides insignificantly decreased $(\mathrm{P}>0.05)$ after adding quinoa hay to the ration. This result is in agreement with Pasko et al. (2010) who reported that feeding rats on quinoa seeds led to effectively reduced total cholesterol and triglycerides.

In the current study, insignificantly $(\mathrm{P}>0.05)$ decrease in plasma cholesterol concentration was observed by consuming quinoa hay compared to control group (Table 5). This finding is consistent with Tomotake et al. (2007), Wang et al. (2009) and Pasko et al. (2010) who reported that some proteins from pseudo cereals (amaranth, buckwheat or quinoa) can affect on level of total cholesterol serum. Also, Takao et al. (2005) and Ryan et al. (2007) suggest that the hypocholesterolemic effect of quinoa may be caused by the saponins, fiber or squalene.

In the present study, the results of Table 5 showed that using the level of $25 \%$ from quinoa hay did not affect creatinine level compared to control group and the same results was reported by Pasko et al. (2010) after adding quinoa seeds to the ration. While, a significant increase $(\mathrm{P}<0.05)$ was observed in the values of creatinine in the rabbits groups received $50 \%$ and $75 \%$ quinoa hay compared to that received $25 \%$ quinoa hay and control group.

Conclusively, from these results, it could be concluded that quinoa hay can be successfully used with $25 \%$ from dietary alfalfa hay as a source of fiber to replace alfalfa hay in the rabbit ration without any negative effect on rabbit performance. The use of quinoa hay in animal rations can be an alternative solution to environmental problems in some regions where other species cannot grow due to salinity and dry of soils.

\section{REFERENCES}

Abdel-Azeem, F. and N.E., El-Bordeny (2007). Utilization of palm tree leaves in feeding growing rabbits. Egyptian J. Nutrition and Feeds, 10 (2): $275-288$.

AOAC. (2016). Official Methods of Analysis International. $20^{\text {th }}$ Ed. Association of Official Agricultural Chemists, Washington, D.C., U.S.A.

Ashour, G.; S. A. Ibrahim; A. M. Ismail and K. H. El-Kholy (2004). Physiological reactions and biological performance of rabbits to summer heat stress. 2nd Sci. Conf. on Physio. Resp. to Environ. Condi., 28-31 July, 2004, El-Arish, Egypt, pp. 165-186. 
Barros-Rodríguez, M.; M. Cajas-Naranjo; O. Núñez-Torres; R. MeraAndrade; J. Artieda-Rojas; C. Sandoval-Castro and J. SolorioSánchez (2018). In situ rumen degradation kinetics and in vitro gas production of seed, whole plant and Stover of Chenopodium quinoa. Journal of Animal and Plant Sciences, 28: 327-331.

Blanco Callisaya, J. A. (2015). Fodder and Animal Feed. In state of the art report of quinoa in the world in 2013, edited by D. Bazile, D. Bertero \& C. Nieto, 250-266. Rome, Italy: FAO \& CIRAD.

Bhargava, A.; S. Shukla and D. Ohri (2007). Genetic variability and interrelationship among various morphological and quality traits in quinoa (Chenopodium quinoa Willd.). Field Crops Res., 101: 104-116.

Bhargava, A.; S. Shukla and D. Ohri (2006). Chenopodium quinoa-An Indian perspective. Industrial Crops and Products, 23(1): 73-87.

Capelo Baez, W. (1979). Evaluación del potencial forrajero y alimenticio de la quínua dulce " Sajama” y Qiiínua amarga “(Chenopodium quínua, $\mathrm{W}$.) en tres épocas de corte. Tesis de Grado, Esc. Sup. Politécn. Chimborazo, Fac. Ing. Zootecn. Riobamba-Ecuador.

Carmen, M. (1984). Acclimatization of quinoa (Chenpodium quinoa, Willd) and canihua (Chenopodium pallidicaule, Aellen) to Finland. Annales Agriculturae Fenniae, 23:135-144.

Cheeke, P. R.; N.M. Patton and G.S. Tempelton (1982). Rabbit Production. $5^{\text {th }}$ Edition, Interstate printers and publishers, Inc. Danville II., USA.

Cheeke, P.R. (1987). Rabbit Feeding And Nutrition. Academic Press. Orlando, Florida, U.S.A.

Darwinkel, A.; O. Stolen (1998). Understanding the quinoa crop: Guidelines for growing in 2 temperate regions of N.W. Europe. Brochure of the Quinoa Project. AIR 2 Programme - 3 contract \#931426, pp. 20.

Duncan, D. B. (1955). Multiple range and multiple F tests. Biometrics, 11:1-42.

Efe, L. (2017). An alternative food and medicinal crop: quinoa (Chenopodium quinoa). In Proceedings of International Congress on Medicinal and Aromatic Plants: Natural and Healthy Life, 288-292. ISBN: 978-6054988-26-6.

El Sayed, A. M. (2016). Evaluation of chenopodium quinoa willd as a new forage crop under Egyptian condition. M.Sc., Fac. Agric., Ain Shams Univ., Egypt.

FAO (1994). Plant Production and Protection Series, in: Hernández, J.E, León, J. (Eds.), Neglected crops 1492 from a different perspective. No.26; ISBN 92-5-103217-3. 
Gugołek, A.; J. Juśkiewicz; D. Kowalska; C. Zwolińsk; P. Sobiech; and J. Strychalski (2018). Physiological responses of rabbits fed with diets containing rapeseed meal, white lupine and pea seeds as soybean meal substitutes. Ciência e Agrotecnologia, 42(3):297-306.

Jacobsen, S. E.; A. Mujica and C. R. Jensen (2003). The resistance of quinoa (Chenopodium quinoa Willd.) to adverse abiotic factors. Food Rev. Int. 19, 99-109, doi:10.1081/FRI120018872.

Jones E. A. and P. D. Bark (1979). Chemical diagnosis of disease. In: Brown S. S., Mitchell F. L., Young D. S. (Ed). Elsevier Biomed. Press, Amsterdam, Netherlands. pp.: 325-363.

Marino, R.; M. Caroprese; G. Annicchiarico; F. Ciampi; M. G. Ciliberti; A. D. Malva; A. Santillo; A. Sevi and M. Albenzio (2018). Effect of Diet Supplementation with Quinoa Seed and/or Linseed on Immune Response, Productivity and Meat Quality in Merinos Derived Lambs Rosaria Marino. Animals, 8 (204): 1-13, doi:10.3390/ani8110204.

Mosquera, M.; S. Portilla and F. Lopez (2009). Nutritional effect evaluation of quinoa (chenopodium quinoa willdenow) with different levels of inclusion in diets for broiler chickens. Facultad de ciencias agropecuarias 7(1):76-90.

NRC (1977). National Research Council. Nutrient Requirements Of Domestic animals. Nutrient Requirement Of Rabbits, 2nd revised edition. USA National Academy of Science. Washington, D.C.

Pasko, P.; P. Zagrodzki; H. J. Barton; J. Chlopica and S. Gorinstein (2010). Effect of Quinoa Seeds (Chenopodium quinoa) in Diet on some Biochemical Parameters and Essential Elements in Blood of High Fructose-Fed Rats. Plant Foods Hum. Nutr., 65:333-338.

Peiretti, P. G.; F. Gai and S. Tassone (2013). Fatty acid profile and nutritive value of quinoa (Chenopodium quinoa Willd.) seeds and plants at different growth stages. Animal Feed Science And Technology, 183(12):56-61.

Peiretti, P. G. (2019). Quinoa: Nutritive Quality Of Seeds And Plants In Animal Nutrition. Chapter 5, in book: Quinoa: Cultivation, Nutritional Properties and Effects on Health, Publisher: Nova Science Publishers, Inc., NY.

Rosero, O. L.; D. A. Rosero and D. Lukesova (2010). Determination of the Capacities of the Farmers to Adopt Quinoa Grain (Chenopodium quinoa Willd.) as Potential Feedstuff. Agricultura Tropica et Subtropica , 43(4): $208-315$. 
Ryan, E.; K. Galvin; T. O'Connor; A. Maguire and N. O'Brien (2007). Phytosterol, squalene, tocopherol content and fatty acid profile of selected seeds, grains, and legumes. Plant Foods Hum. Nutr., 62:85-91.

SAS (2003). SAS/STAT User's Guide (Version 9.2). Statistical Analysis System Inst, Cary, NC.

Shahidi, F. and M. Naczk (1995). Food Phenolics: Sources, Chemistry, Effects and Applications. Technomic Publishing Co., Lancaster.

Takao, T.; N. Watanabe; K. Yuhara; S. Itoh; S. Suda; Y. Tsuruoka; K. Nakatsugawa and Y. Konishi (2005). Hypocholesterolemic effect of protein isolated from quinoa (Chenopodium quinoa Wild.) seeds. Food Sci., Technol., Res., 11:161-167.

Tomotake, H.; N. Yamamoto; H. Kitabayashi; A. Kawakami; J. Kayashita; H. Ohinata; H. Karasawa and N. Kato (2007). Preparation of tartary buckwheat protein product and its improving effect on cholesterol metabolism in rats and mice fed cholesterol-enriched diet. Journal of Food Sci, 72:528-533.

XU, X.Q. and Z. Q. Zhang, (2000). Kinetic Spectrophotometric Determination of Oxalic cid Based on the Catalytic Oxidation of Bromophenol Blue by Dichromate. Mikrochim. Acta, 135: 169-172.

Van Soest, P.J.; J. B. Robertson and B. A. Lewis (1991). Methods for dietary fibre, neutral detergent fibre and non-starch polysaccharides in relation to animal nutrition. Journal of Dairy Sci., 74: 3583-3597.

Vilcacundo, R. and L. B. Hernández (2017). Nutritional and biological value of quinoa (Chenopodium quinoa Willd.). Current Opinion In Food Science 2017 v.14 pp. 1-6, doi:10.1016/j.cofs.2016.11.007.

Wang, C.; Y. Zhu; F. Li and L. Huang (2017). The Effect of Lactobacillus isolates on growth performance, immune response, intestinal bacterial community composition of growing Rex Rabbits. Journal of Animal Physiology and Animal Nutrition, 101, doi:10.1111/jpn.12629.

Wang, M.; J. Liu; J. Gao; J. Parry and Y. Wei (2009). Antioxidant activity of tartary buckwheat bran extract and its effect on the lipid profile of hyper lipidemic rats. J. Agric Food Chem 57:5106-5112. 


\section{تأثير إستخدام مستويات مختلفة من دريس الكينوا فى علائق الأراتب النامية}

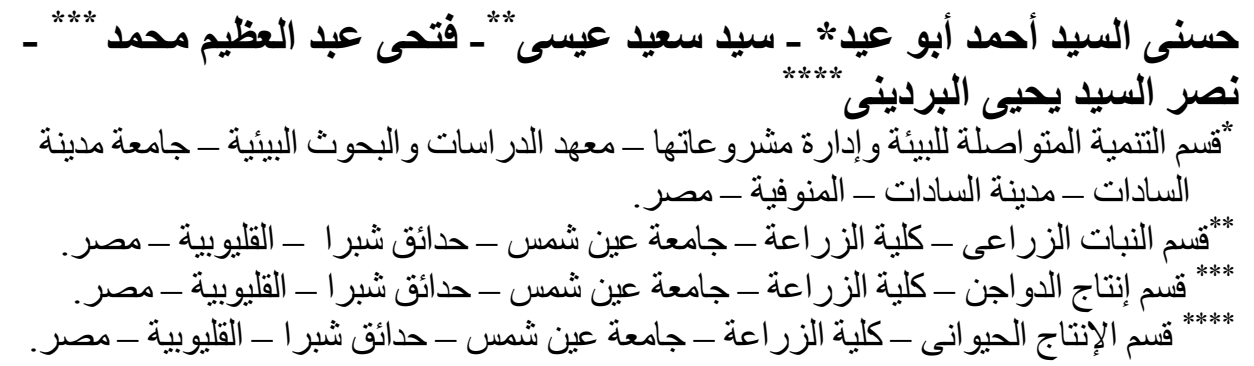

أجريت الدراسة الحالية لبحث تأثير إحلال مستويات مختلفة 25 و 50 و و

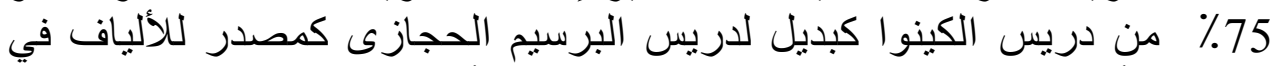

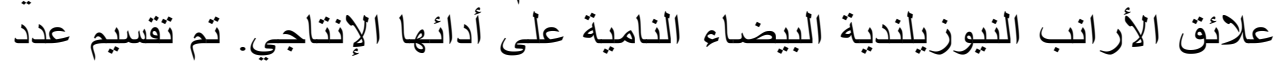

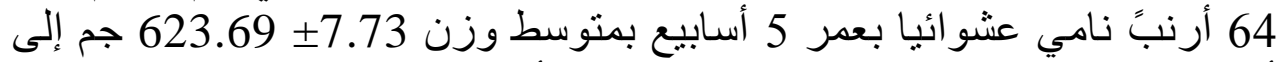

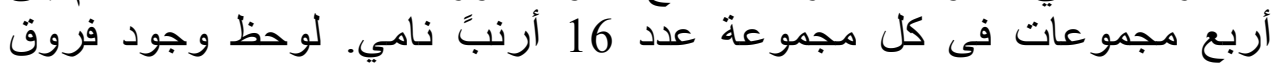

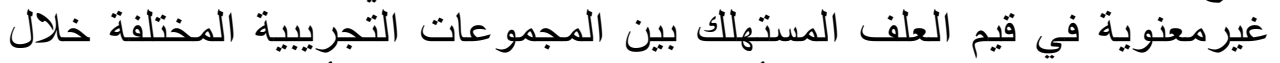

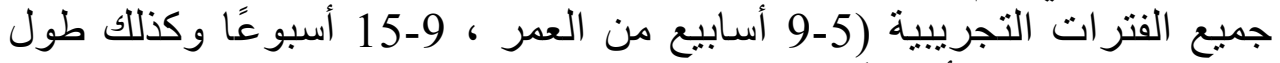
فترة التجربة 5-15 أسبو عًا من العمر).

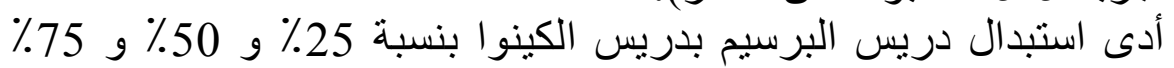

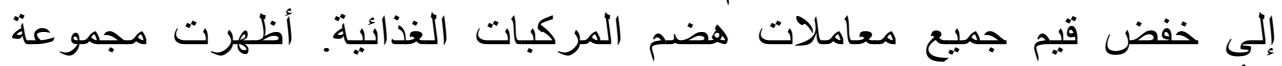

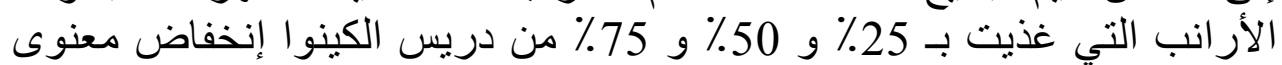

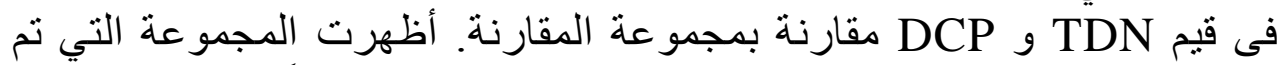

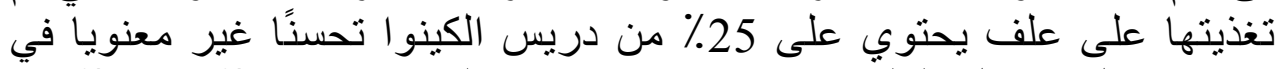

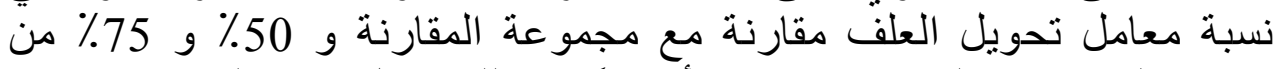
دريس الكينو ا في الفترة من 9-15 أسبو عًا وكذللك خلال فترة التجربة (5-15 منة

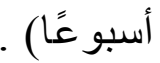
لوحظ زيادة غير معنوية في قيم البروتين الكلي والألبومين و الجلوبيولين

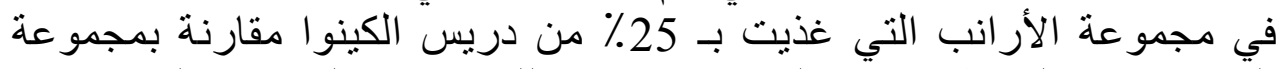

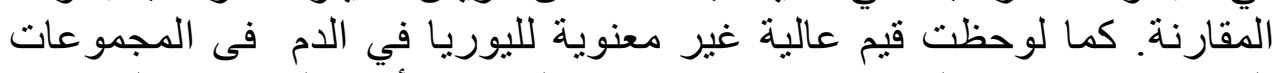

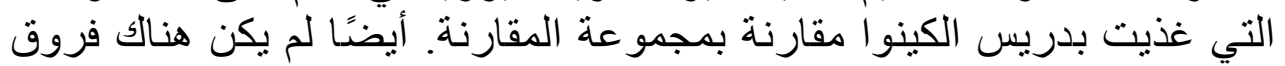

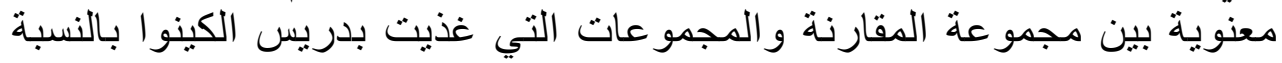

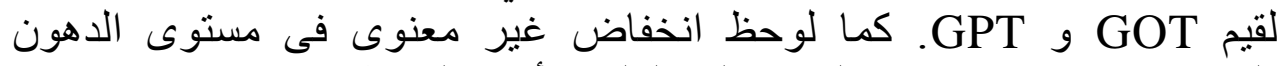

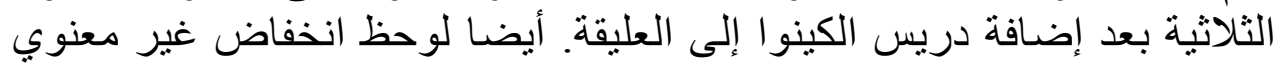
في تركيز الكوليسترول في بلازما الدم عند تناول دريس الكينوا مقارنة 


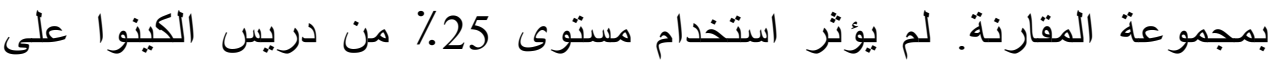

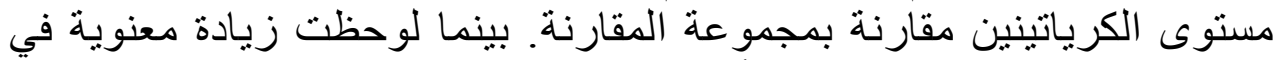

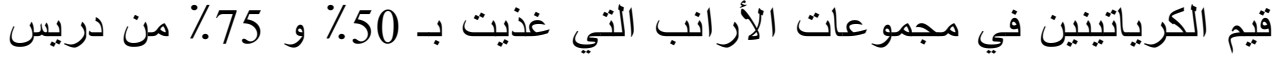

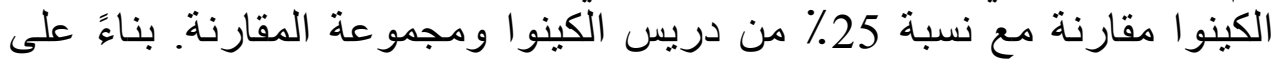

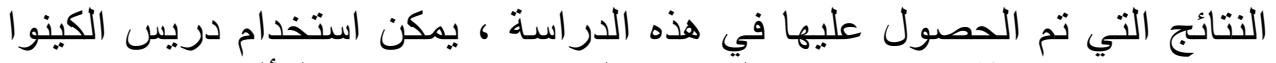

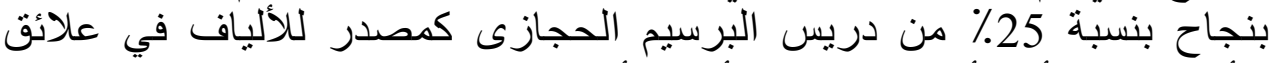
الأرانب دون أي تأثنير سلبي على من أداء الأر انب.

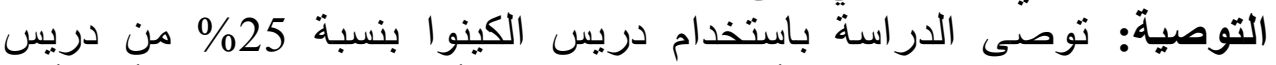
البرسيم الحجازى كمصدر للألياف فى علائق الأرانب النامية درية دون أنى تأثير سلبى على آدائها. الكلمات الدالة: دريس الكينو الدانه - الأرانب - القيم الغذائية ـ الآداء - الهضم -

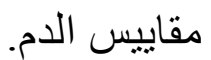

